\title{
The Potential Effect of Fatty Acids from Pliek $U$ on Epidermal Fatty Acid Binding Protein: Chromatography and Bioinformatic Studies
}

(Potensi Kesan Asid Lemak daripada Pliek U pada Epidermis Asid Lemak Pengikat Protein: Kajian Kromatografi dan Bioinformatik)

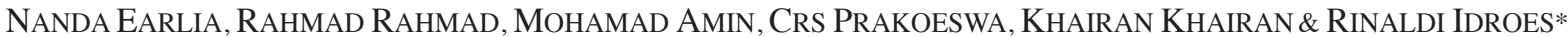

\section{ABSTRACT}

The fatty acid analysis in Pliek U and its bioinformatic studies had been carried out and reported. Herein, fatty acids were analyzed by gas chromatography-mass spectrometry (GC-MS), meanwhile their potential effect, based on its interaction on epidermal fatty acid binding protein (E-FABP), was studied by bioinformatics approach with reverse docking technique using palmitic acid as a control compound. For the stated purpose, two Pliek U extracts were prepared, namely ethanolic Pliek U extract (EPUE), and ethanolic of residue hexane of Pliek U extract (ERHPUE). The GC-MS results showed that lauric, myristic, palmitic, and oleic acids were predominant, followed by stearic, capric, linoleic, and caprylic acids. Reverse docking results showed that linoleic acid had the lowest binding affinity (-5.9 kcal/mol) and was strongly bound to E-FABP on the same side of amino acid GLN A98, ARG A81, TYR A22, and LYS A61. These findings indicated that linoleic acid has a potential utility as a drug candidate for atopic dermatitis treatment.

Keywords: Atopic dermatitis; bioinformatics; E-FABP; fatty acid; gas chromatography; Pliek U

\section{ABSTRAK}

Analisis asid lemak pada Pliek U dan kajian bioinformatiknya telah dijalankan dan dilaporkan. Di sini, asid lemak telah dianalisis menggunakan spektrometri gas kromatografi - jisim (GC-MS), sementara kesan potensinya berdasarkan interaksi pada epidermis asid lemak pengikat protein (E-FABP), dikaji menggunakan kaedah bioinformatik dengan teknik dok berbalik menggunakan asid palmitik sebagai sebatian kawalan. Untuk maksud yang dinyatakan, dua ekstrak Pliek U telah disediakan; ekstrak etanolik Pliek U (EPUE) dan ekstrak etanolik sisa heksana Pliek U (ERHPUE). Keputusan GC-MS menunjukkan asid laurik, miristik, palmitik dan oleik adalah pradominan, diikuti oleh asid stearik, caprik, linoleik dan caprilik. Keputusan dok berbalik menunjukkan asid linoleik mempunyai pengikat afiniti terendah (-5.9 kcal/mol) dan terikat dengan kuat kepada E-FABP pada sisi yang sama dengan asid amino GLN A98, ARG A81, TYR A22 dan LYS A61. Penemuan ini menunjukkan asid linoleik mempunyai potensi utiliti sebagai calon dadah untuk rawatan dermatitis atopik.

Kata kunci: Asid lemak; dermatitis atopik; bioinformatik; E-FABP; kromatografi gas; Pliek U

\section{INTRODUCTION}

The fatty acid is one of three mayor lipids in stratum corneum (Elias 2014; Jungersted et al. 2008; McCusker \& Grant-Kels 2010). Along with filaggrin, it becomes a major component in the lipid-protein matrix, which functions as a protective barrier on the skin (Sandilands et al. 2009; van Smeden et al. 2014)loss-of-function mutations in FLG, the human gene encoding profilaggrin and filaggrin, have been identified as the cause of the common skin condition ichthyosis vulgaris (which is characterised by dry, scaly skin. A deficiency of fatty acid in stratum corneum is one of the causes of skin barrier disfunction, especially in atopic dermatitis disease. It can be caused by a fatty acid biosynthesis problem or mechanical damage due to a secondary disease such as pruritus (Thyssen \& Kezic 2014).

A medical treatment to repair the skin barrier disfunction caused by fatty acid deficiency is fatty acid cream therapy. The cream is used as a pharmaceutical media to attach a fatty acid content to external disease target. Due to their hydrophobicity, fatty acids are virtually insoluble in body fluid. Their movement between cell membranes requires a special mechanism that involves a transport protein. The epidermal fatty acid binding protein (E-FABP), predominantly produced in the epidermis, is reported to have a role in transport protein process (Ogawa et al. 2011; Owada et al. 2002).

The fatty acid source to supply a drug requirement can be obtained from animal or plant (Jumat et al. 2010), one of them is coconut. In Indonesia, coconut is one of the prominent agricultural commodities. In Bireuen District, Aceh Province, coconut meat is traditionally processed through natural fermentation to produce fermentedcoconut oil called Pliek $U$ Oil. This process also produces a secondary product called Pliek $U$ (fermented coconut meat) (Vaughn 2018). Pliek $U$ is commonly used as an ingredient in the traditional culinary by the local people (Arpi 2013), 
whereas the fatty acid content in this coconut product has a potential to be used as a pharmacy resource.

It is important to know the detail fatty acid content in coconut product when it is used to medical purposes. Every fatty acid gives different drug activities depending on the fit between the fatty acid structure and the protein receptor. In another hand, the geographic factor always influences the fatty acid content in coconut cultivated from different locations, varieties of crop (Laureles et al. 2002), times of harvesting (Carandang 2008) and age of nuts (Balleza \& Sierra 1976). Gas chromatography analysis has been reported as a good method to analyze fatty acid of coconut meat product. Non-volatile property of fatty acid was resolved with derivatization of its extract to be volatile compounds (Azeez 2007; Jumat et al. 2014; Laureles et al. 2002).

A drug activity of fatty acid in case of atopic dermatitis treatment is assessed firstly with E-FABP protein. This protein transports the fatty acid to drug target (filaggrin) in stratum corneum. So that, the best fit of fatty acid content with E-FABP will affect the drug activity of fatty acid to treat atopic dermatitis. To study the drug activity, a virtual screening method using molecular docking has been proposed. This computational method gives the way to minimize several bio laboratory experiments (Hurle et al. 2013). In the laboratory, the interaction between a compound with protein is studied through spectroscopy approach such as UV-Vis absorption that involve chemical materials and chemical process (Suhartono et al.2018). Whereas the computational method is performed through modeling using chemical structure database, therefore, the research becomes more time saving and cost-efficient.

In this research, the fatty acids of Pliek $U$ were analyzed by gas chromatography-mass spectrometry (GC-MS) and the potential drug activities of fatty acids to E-FABP were studied by reverse docking technique.

\section{MATERIALS AND METHODS}

\section{SAMPLE EXTRACTION}

Samples were purchased from Pliek $U$ home industry in Matang Subdistrict, Bireuen District, Aceh Province. Pliek $U$ was selected based on purposive sampling technique, with the criterium to be newly produced. Afterward, Pliek $U$ was prepared to produce ethanolic Pliek $U$ extract (EPUE) and ethanolic hexane residue Pliek $U$ extract (EHRPUE).

As much as $250 \mathrm{~g}$ Pliek $U$ was macerated with $1.5 \mathrm{~L}$ ethanol $96 \%$. The mixture was put in a shaker at $130 \mathrm{rpm}$ and $28^{\circ} \mathrm{C}$ for $48 \mathrm{~h}$. It was filtered using vacuum filtration to obtain the macerate and residue. The obtained residue was re-extracted twice using separating funnel with 300 $\mathrm{mL}$ ethanol $96 \%$. The filtrate was mixed with macerate and concentrated with rotary evaporator at $50^{\circ} \mathrm{C}$. This procedure gives a result to ethanolic Pliek $U$ extract (EPUE).

As much as $250 \mathrm{~g}$ Pliek $U$ was macerated with 1.5 $\mathrm{L} \mathrm{n}$-hexane. The mixture was put in a shaker at $130 \mathrm{rpm}$ and $28^{\circ} \mathrm{C}$ for $48 \mathrm{~h}$. It was filtered using vacuum filtration to obtain the macerate and residue. The obtained residue was re-extracted twice using separating funnel with 300 $\mathrm{mL} n$-hexane. The obtained residue was remacerated using separating funnel with 1.5 Lethanol $96 \%$. All macerate and filtrate were mixed and concentrated with rotary evaporator at $50^{\circ} \mathrm{C}$. This procedure gives a result to ethanolic hexane residue Pliek $U$ extract (EHRPUE).

\section{SAMPLE PREPARATION FOR GC-MS ANALYSIS}

Samples were weighed $1 \mathrm{~g}$ (EPUE and EHRPUE). Four $\mathrm{mL}$ n-hexane p.a was added into each sample and vortexed for $2 \mathrm{~min}$. The clear hexane extract was taken and transferred to the derivation tube, then dried with nitrogen bursts. Two $\mathrm{mL}$ of $2 \% \mathrm{NaOH}(\mathrm{NaOH}$ in methanol), sealed tightly and heated at $90^{\circ} \mathrm{C}$ for $5 \mathrm{~min}$. After left to cool down, $2 \mathrm{~mL}$ of $\mathrm{BF}_{3}$ in methanol, it was sealed tightly and reheated for $30 \mathrm{~min}$. Then it was left until cold, before being extracted with $3 \mathrm{~mL}$ n-hexane p.a. The upper phase (n-hexane) was taken for GC-MS analysis.

\section{GC-MS DATA ANALYSIS}

The fatty acid compounds were analyzed by the peaks of the chromatogram based on MS data analysis. The area percentage (\%) of each peak was used to determine the content percentage of fatty acid, which later was employed in the determination of predominant fatty acid within each sample.

\section{PROCESS OF DOCKING}

Prior to docking, the determination of the control compound, palmitic acid $\left(\mathrm{C}_{16} \mathrm{H}_{32} \mathrm{O}_{2}\right)$, is required. After that, the 3D structure of target compounds was downloaded from PubChem database, meanwhile the 3D structure of the protein is downloaded from the database of Protein Data Bank (GDP). Then, the natural ligand on target protein was cut using PyMOl application (https://pymol. en.softonic.com/?ex=DSK-1262.10). After all information were collected, the docking process between the control compound and prediction compound of the target protein using PyRx computer application (https://pyrx.sourceforge. io/downloads) was carried out.

\section{VISUALIZATION OF DOCKING RESULT}

Visualization of docking result was carried out by two software, namely PyMol and Discovery Studio (https:// www.3dsbiovia.com/products/collaborative-science/ biovia-discovery-studio/visualization-download.php).

\section{RESULTS AND DISCUSSION}

\section{FATTY ACIDS ANALYSIS OF PLIEK $U$ BY GC-MS}

GC-MS analysis showed that the predominant fatty acid content in both ethanolic extract (EPU) and ethanolic residual hexane (ERHPUE) extract was similar. Each sample 
had a different percentage of fatty acids (Table 1). Lauric acid was the highest fatty acid contained in samples (EPUE = $35,68 \%$ and ERHPUE $=29.70 \%$ ), and followed by myristic acid $($ EPUE $=21.48 \%$ and ERHPUE $=25.06 \%$, palmitic acid $($ EPUE $=13.72 \%$ and ERHPUE $=16.04 \%)$, oleic acid (EPUE $=11.98 \%$ and ERHPUE $=10.40 \%)$, stearic acid $($ EPUE $=$ $5.17 \%$ and ERHPUE $=4.42 \%)$, capric acid (EPUE $=4.02 \%$ and ERHPUE $=4.94 \%)$, linoleic acid $($ EPUE $=3.68 \%$ and ERHPUE $=2.07 \%)$, and caprylic acid $($ EPUE $=3.32 \%$ and ERHPUE $=3.84 \%$ ). Other fatty acid contents were detected less than $1 \%$.

Based on GC-MS data, the predominant fatty acid contents in Pliek $U$ was similar to the predominant fatty acid contents in coconut oil. The fatty acid contents in coconut oil were also dominated by lauric acid, mirystic acid and caprylic acid (Orsavova et al. 2015; Lin et al. 2018). Therefore, Pliek $U$ had the potential to be used for medical purposes, especially as a medical resource in drug therapy to treat atopic dermatitis.

\section{MOLECULAR DOCKING STUDY BASED ON BINDING AFFINITY VALUE}

Molecular docking was performed using the 3D structure of the target E-FABP protein with ligands (caprylic acid, capric acid, lauric acid, linoleic acid, myristic acid, and oleic acid) and a control ligand (palmitic acid). The results of common virtual docking using PyRx software is the affinity binding value of each ligand presented in Table 2 .
The binding affinity between palmitic acid (control ligand) and E-FABP was $-5.8 \mathrm{Kcal} / \mathrm{mol}$. Based on the binding affinity between ligand and E-FABP, only linoleic acid had a lower binding affinity compared to the control ligand $(-5.9 \mathrm{Kcal} / \mathrm{mol})$. The binding affinity value is important to identify the molecular and macromolecular interaction because it is the first role to facilitate the discovery and development of new drugs (Cournia et al. 2017; Du et al. 2016; Rufaidah et al. 2017). The low binding affinity allows linoleic acid to have the great potential to bind E-FABP (target protein) with less energy, whereas it was not found in other fatty acids.

Gibbs energy theory states that the smaller the energy generated from a bond between the ligand and its receptor, the more stable the bond is. Therefore, the low binding affinity increases the stability of interaction between fatty acid and E-FABP (Lukitaningsih et al. 2015). The research on mice that did not have E-FABP, as reported by Ogawa et al. (2011), showed a reduction of linoleic acid compared to other fatty acids. This ascribes that linoleic acid is the main fatty acid that interacts with E-FABP.

\section{VISUALIZATION OF INTERACTION BETWEEN FATTY ACID AND E-FABP}

Using pyMOL software, interactions between predicted ligand (fatty acids) and target protein (E-FABP) were visualized side by side. The interactions were compared to the interaction between control ligand (palmitic acid)

TABLE 1. Fatty acids analysis from EPUE and ERHPUE by GC-MS

\begin{tabular}{lcc}
\hline Component & EPUE & ERHPUE \\
\hline Caprylic acid & $3.23 \%$ & $3.84 \%$ \\
Capric acid & $4.02 \%$ & $4.94 \%$ \\
Lauric acid & $35.68 \%$ & $29.70 \%$ \\
Methylestertridecanoic acid & - & $0.06 \%$ \\
Myristic acid & $21.48 \%$ & $25.06 \%$ \\
Methylesterpentadecanoic acid & - & $0.06 \%$ \\
Palmitoleic acid & - & $0.29 \%$ \\
Palmitic acid & $13.72 \%$ & $16.04 \%$ \\
Linoleic acid & $3.68 \%$ & $2.07 \%$ \\
Oleic acid & $11.98 \%$ & $10.40 \%$ \\
Elaidic acid & $0.71 \%$ & $0.42 \%$ \\
Stearic acid & $5.17 \%$ & $4.42 \%$ \\
Methylestereicosenoic acid & - & $0.05 \%$ \\
Arakat acid & - & $0.11 \%$ \\
Lignoceric acid & - & $0.10 \%$ \\
\hline
\end{tabular}

TABLE 2. Binding affinity between predictive ligands and E-FABP

\begin{tabular}{clc}
\hline No & Ligands & Binding Affinity $(\mathrm{Kcal} / \mathrm{mol})$ \\
\hline 1 & Capric acid & -4.8 \\
2 & Caprylic acid & -4.9 \\
3 & Lauric acid & -5.1 \\
4 & Linoleic acid & -5.9 \\
5 & Mirystic acid & -5.7 \\
6 & Oleic acid & -5.8 \\
7 & Palmitic acid & -5.8 \\
\hline
\end{tabular}


and E-FABP. The best interaction was justified based on the similarity of interaction between predicted ligand and E-FABP with control ligand and E-FABP. It was known that palmitic acid bound to E-FABP on amino acid residues of TYR A22, ARG A81, GLN A98, and LYS A61. The interaction visualizations of each ligand to E-FABP were described as follows:

\section{Visualization of the interaction between Capric acid and E-FABP}

The visualization of capric acid and E-FABP interaction (Figure 1) showed the presence of hydrogen bonds and hydrophobic interactions. Hydrogen bonds occurred in the amino acid of ARG A81, while hydrophobic interactions occurred in amino acids of MET A23 and PHE A19. It can be concluded that the capric acid and palmitic acid bounded the same sides of E-FABP on amino acid of ARG A81.

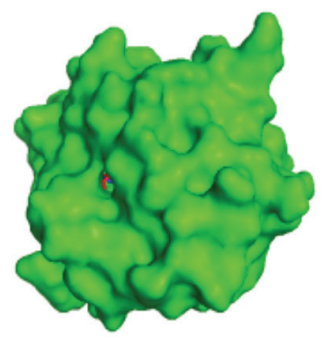

(a)

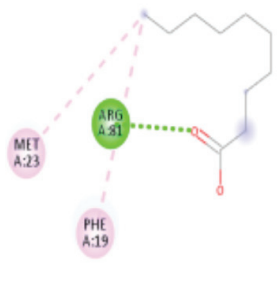

(b)
FIGURE 1. The docking result of capric acid and palmitic acid with E-FABP. (a) 3D visualization: capric acid (red) and palmitic acid (blue) and (b) 2D visualization: amino acid residues in capric acid and palmitic acid

Visualization of the interaction between Caprylic acid and E-FABP

The visualization of caprylic acid and E-FABP interaction (Figure 2) showed the presence of hydrogen bonds and hydrophobic interactions. Hydrogen bonds occurred in amino acids of GLN A98, ARG A81, and TYR A22, meanwhile the hydrophobic interaction occurred in amino acids of TYR A131, ARG A129 and VAL A118. It can be concluded that caprylic acid and palmitic acid bounded the same sides of E-FABP on amino acids of GLN A98, ARG A81, and TYR A22.

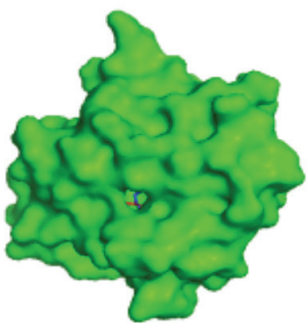

(a)

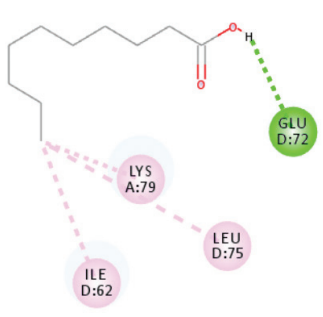

(b)
FIGURE 2. The docking result of caprylic acid and palmitic acid with E-FABP. (a) 3D visualization of caprylic acid (blue) and palmitic acid (red) and (b) 2D visualization of amino acid residues in caprylic acid and palmitic acid
Visualization of the interaction between Lauric acid and E-FABP

The visualization of lauric acid and E-FABP interaction (Figure 3 ) showed the presence of hydrogen bonds and hydrophobic interactions. Hydrogen bonds occurred in amino acids of TYR A22, and GLN A98, meanwhile the hydrophobic interactions occurred in amino acids of ALA A78 and PHE A19. It can be concluded that lauric acid and palmitic acid bounded the same sides of E-FABP on amino acids of TYR A22 and GLN A98.

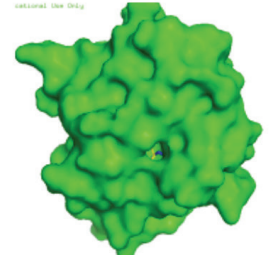

(a)

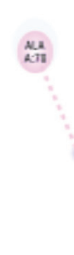

(b)

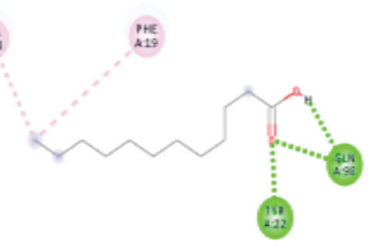

FIGURE 3. The docking results of lauric acid and palmitic acid with E-FABP. (a) 3D visualization of lauric acid (yellow) and palmitic acid (blue) and (b) 2D visualization of amino acid residues in lauric acid and palmitic acid

Visualization of the interaction between Myristic acid and E-FABP

The visualization of myristic acid and E-FABP interaction (Figure 4) indicated the presence of hydrogen bonds and hydrophobic interactions. Hydrogen bonds occurred in the amino acids of THR A56 and ARG A809, while hydrophobic interactions occurred in the amino acids of MET A23 and PHE A19. It can be concluded that myristic acid and palmitic acid did not bind E-FABP to any same side.

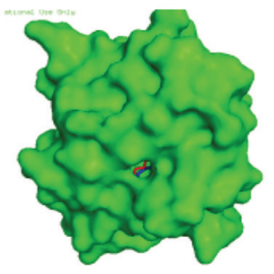

(a)

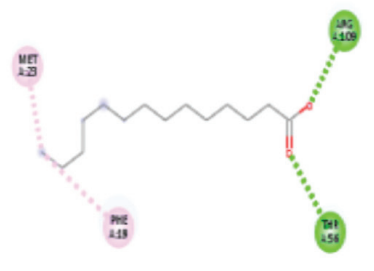

(b)
FIGURE 4. The docking result of myristic acid and palmitic acid with E-FABP. (a) 3D visualization of myristic acid (red) and palmitic acid (blue) and (b) 2D visualization of amino acid residues in myristic acid and palmitic acid

Visualization of the interaction between Oleic acid and E-FABP

The visualization of oleic acid and E-FABP (Figure 5) interaction indicated the presence of hydrogen bonds and hydrophobic interactions. Hydrogen bonds occurred in the amino acid of TYR A56, and hydrophobic interactions occurred in the amino acids of MET A23, LEU A56, and PHE A19. It can be concluded that oleic acid and palmitic acid did not bind E-FABP to any same side. 


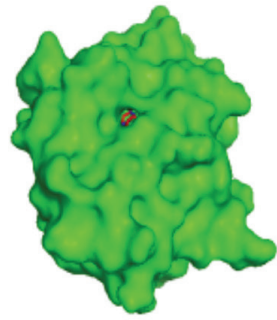

(a)

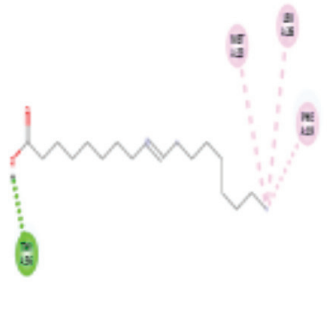

(b)
FIGURE 5. The docking result of oleic acid and palmitic acid with E-FABP. (a) 3D visualization of oleic acid (orange) and palmitic acid (grey) and (b) 2D visualization of amino acid residues in oleic acid and palmitic acid

\section{Visualization of the interaction between Linoleic acid and E-FABP}

The visualization of linoleic acid and E-FABP interaction (Figure 6) showed the presence of hydrogen bonds and hydrophobic interactions. Hydrogen bonds occurred in the amino acids of TYR A22, ARG A81, and GLN A98, while hydrophobic interactions occurred in the amino acids of PRO A41, LYS A61, and ALA A39. It can be concluded that linoleic acid and palmitic acid bounded the same sides of E-FABP on amino acids of GLN A98, ARG A81, TYR A22, and LYS A61.

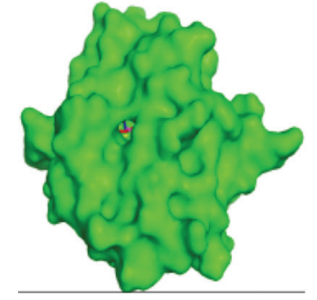

(a)

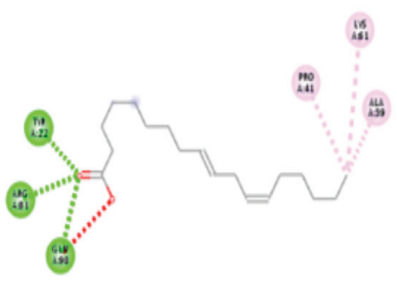

(b)
FIGURE 6 . The docking result of linoleic acid and palmitic acid with E-FABP. (a) 3D visualization of linoleic acid (red) and palmitic acid (yellow) and (b) 2D visualization of amino acid residues in linoleic acid and palmitic acid

Visualization of the interactions between all predicted ligands (fatty acids) and protein target (E-FABP) showed that myristic and oleic acids did not have any same side bound to E-FABP. Capric, caprylic and lauric acids had some same sides bound to E-FABP. Especially for linoleic acid, it had all the same sides bound to E-FABP. Based on this result, it can be concluded that linoleic acid had the best structural conformation to bind E-FABP with the best orientation of interaction.

According to the molecular docking analysis, both binding affinity and orientation of interaction, linoleic acid had the best potential to be a drug candidate in atopic dermatitis treatment. These fatty acids showed stable interaction and the best orientation of interaction to interact with E-FABP. Hence, linoleic acid can efficiently transport to stratum corneum where filaggrin, the drug target, was located. Linoleic acid content in both EPUE and EHRPUE extracts showed that Pliek $U$ had a great potential to be used as a drug resource and natural active ingredient for atopic dermatitis cream therapy.

This result was also in line with the research, reported by Ogawa et al. (2011), that E-FABP deletion resulted in a decrease of cellular linoleic acid, followed by a decrease of linoleic acid derivative, 13-hydroxyoctadecadienoic acid (13-HODE), the major metabolite of linoleic acid in the skin. Whereas, arachidonic and linolenic acids content remained unchanged suggesting that E-FABP and linoleic acid bound each other with higher affinity in keratinocytes (Ogawa et al. 2011). Furthermore, E-FABP induces keratinocyte differentiation and enhances the transcriptional activity of peroxisome proliferator-activated receptors (PPARs) by directly targeting fatty acid to PPARß (Owada et al. 2002).

\section{CONCLUSION}

Pliek $U$ extracts had been successfully analyzed by GC MS. The analysis result showed that lauric, myristic, palmitic, and oleic acids were predominant and followed by stearic, capric, linoleic, and caprylic acids. Based on molecular docking analysis, linoleic acid showed stable interaction and the best orientation of interaction to interact with E-FABP. Therefore, linoleic acid had the best potential as a drug candidate for atopic dermatitis treatment.

\section{ACKNOWLEDGEMENTS}

The authors wish to thank Department of Biology, Faculty of Mathematics and Natural Sciences, Universitas Negeri Malang and Department of Chemistry, Faculty of Mathematics and Natural Sciences, Universitas Syiah Kuala for a laboratory facilities during this study.

\section{REFERENCES}

Arpi, Normalina. 2013. Pembuatan minyak kemenyan (minyak obat tradisional khas aceh) dengan variasi jenis bahan baku minyak dan konsentrasi bahan pewangi. Jurnal Teknologi dan Industri Pertanian Indonesia 5(1). https://doi.org/10.17969/ jtipi.v5i1.998.

Azeez, Shamina. 2007. Fatty acid profile of coconut oil in relation to nut maturity and season in selected cultivars/ hybrids. British Food Journal 109(4): 272-279. https://doi. org/10.1108/00070700710736525.

Balleza, C.F. \& Sierra, Z.N. 1976. Proximate analysis of the coconut endosperm in progressive stages of development. Philippines Journal of Crop Science 1: 37-44.

Carandang, E.V. 2008. Health benefits of virgin coconut oil. Indian Coconut Journal-Cochin-38(9): 8.

Cournia, Z., Bryce, A. \& Woody S. 2017. Relative binding free energy calculations in drug discovery: Recent advances and practical considerations. Journal of Chemical Information and Modeling 57(12): 2911-2937. https://doi.org/10.1021/ acs.jcim. $7 \mathrm{~b} 00564$.

Du, X., Li, Y., Xia, Y-L., Ai, S-M., Liang, J., Sang, P., Ji, X-L. \& Liu, S-Q. 2016. Insights into protein-ligand interactions: 
mechanisms, models, and methods. International Journal of Molecular Sciences 17(2): E144. https://doi.org/10.3390/ ijms17020144.

Elias, P.M. 2014. Lipid abnormalities and lipid-based repair strategies in atopic dermatitis. Biochimica et Biophysica Acta (BBA) - Molecular and Cell Biology of Lipids 1841(3): 323330. https://doi.org/10.1016/j.bbalip.2013.10.001.

Hurle, M.R., Yang, L., Xie, Q., Rajpal, D.K., Sanseau, P. \& Agarwal, P. 2013. Computational drug repositioning: From data to therapeutics. Clinical Pharmacology \& Therapeutics 93(4): 335-341. https://doi.org/10.1038/clpt.2013.1.

Jumat Salimon, Talal Ahmed \& Nadia Salih. 2014. Quantitative gas chromatographic method for the analysis of cis and trans fatty acid in margarines. Sains Malaysiana 43(12): 19371942. https://doi.org/10.17576/jsm-2014-4312-16.

Jumat Salimon, Dina Azleema Mohd Noor, A.T. Nazrizawati, M.Y. Mohd Firdaus \& A. Noraishah. 2010. Fatty acid composition and physicochemical properties of Malaysian castor bean Ricinus communis L. seed oil'. Sains Malaysiana 39(5): 761-764.

Jungersted, J.M., Hellgren, L.I., Jemec, G.B. \& Agner, T. 2008. Lipids and skin barrier function - A clinical perspective. Contact Dermatitis 58(5): 255-262. https://doi.org/10.1111/ j.1600-0536.2008.01320.x.

Laureles, L.R., Rodriguez, F.M., Reaño, C.E., Santos, G.A., Laurena, A.C. \& Tecson Mendoza, E.M. 2002. Variability in fatty acid and triacylglycerol composition of the oil of coconut (Cocos nucifera L.) hybrids and their parentals. Journal of Agricultural and Food Chemistry 50(6): 1581-1586. https:// doi.org/10.1021/jf010832w.

Lin, T.Z., Zhong, L. \& Santiago, J. 2018. Anti-inflammatory and skin barrier repair effects of topical application of some plant oils. International Journal of Molecular Sciences 19(1): 70. https://doi.org/10.3390/ijms19010070.

Lukitaningsih, Endang, Aditya Wisnusaputra, and B. S. Ari Sudarmanto. 2015. Scrining in silico active compound of Pachyrrhizus erosus as antitirosinase on Aspergillus oryzae (computattional study with homology modeling and molecular docking). Majalah Obat Tradisional 20(1): 7-15. https://doi.org/10.22146/tradmedj.7751.

McCusker, M.M. \& Grant-Kels, J.M. 2010. Healing fats of the skin: The structural and immunologic roles of the $\omega-6$ and $\omega-3$ fatty acids. Clinics in Dermatology 28(4): 440-451. https:// doi.org/10.1016/j.clindermatol.2010.03.020.

Orsavova, J., Misurcova, L., Ambrozova, J., Vicha, R. \& Mlcek, J. 2015. Fatty acids composition of vegetable oils and its contribution to dietary energy intake and dependence of cardiovascular mortality on dietary intake of fatty acids. International Journal of Molecular Sciences 16(12): 1287112890. https://doi.org/10.3390/ijms160612871.

Ogawa, E., Owada, Y., Ikawa, S., Adachi, Y., Egawa, T., Nemoto, K., Suzuki, K., Hishinuma, T., Kawashima, H., Kondo, H., Muto, M., Aiba, S. \& Okuyama, R. 2011. Epidermal fabp (fabp5) regulates keratinocyte differentiation by 13(s)-hodemediated activation of the $\mathrm{nf}-\kappa \mathrm{b}$ signaling pathway. Journal of Investigative Dermatology 131(3): 604-612. https://doi. org/10.1038/jid.2010.342.

Owada, Y., Suzuki, I., Suzuki, R., Kondo, H., Takano, H., Yamanaka, H., Kobayashi, H., Sugitani, Y., Tomioka Y., Terui, T., Mizugaki, M., Tagami, H. \& Noda, T. 2002. Altered water barrier function in epidermal-type fatty acid binding proteindeficient mice. Journal of Investigative Dermatology 118(3): 430-435. https://doi.org/10.1046/j.0022-202x.2001.01616.x.
Sandilands, A., Sutherland, C., Irvine, A.D. \& McLean, W.H.I. 2009. Filaggrin in the Frontline: Role in skin barrier function and disease. Journal of Cell Science 122(9): 1285-1294. https://doi.org/10.1242/jcs.033969.

van Smeden, J., Janssens, M., Kaye, E.C.J., Caspers, P.J., Lavrijsen, A.P., Vreeken, R.J. \& Bouwstra, J.A. 2014. The importance of free fatty acid chain length for the skin barrier function in atopic eczema patients. Experimental Dermatology 23(1): 45-52. https://doi.org/10.1111/exd.12293.

Suhartono, E., I. Thalib, I. Aflanie, Z. Noor, \& R. Idroes. 2018. Study of interaction between cadmium and bovine serum albumin with uv-vis spectrocopy approach. IOP Conference Series: Materials Science and Engineering 350 (May): 012008. https://doi.org/10.1088/1757-899X/350/1/012008.

Thyssen, J.P. \& Kezic, S. 2014. Causes of epidermal filaggrin reduction and their role in the pathogenesis of atopic dermatitis. Journal of Allergy and Clinical Immunology 134(4): 792-799. https://doi.org/10.1016/j.jaci.2014.06.014.

\section{Nanda Earlia}

Graduate School of Mathematics and Applied Sciences

Universitas Syiah Kuala

Banda Aceh, 23111

Indonesia

Rahmad Rahmad \& Rinaldi Idroes*

Department of Chemistry

Faculty Mathematics and Natural Sciences

Universitas Syiah Kuala

Banda Aceh, 23111

Indonesia

Mohamad Amin

Department of Biology

Faculty Mathematics and Natural Sciences

Universitas Negeri Malang

Malang, 65145

Indonesia

CRS Prakoeswa

Faculty of Medicine

Universitas Airlangga - Dr Soetomo General Academic Hospital

Surabaya, 60132

Indonesia

Khairan Khairan \& Rinaldi Idroes*

Department of Pharmacy

Faculty Mathematics and Natural Sciences

Universitas Syiah Kuala

Banda Aceh, 23111

Indonesia

*Corresponding author; email: rinaldi.idroes@unsyiah.ac.id

Received: 15 January 2019

Accepted: 28 March 2019 